\author{
Abstracta Iranica \\ Abstracta Iranica Revue bibliographique pour le domaine irano-aryen \\ Volume 40-41 | 2019 \\ Comptes rendus des publications de 2017-2018
}

\title{
Maria G. Micale. "Clay Figurines in the Persian Achaemenid Near East as Seen from Tell Mardikh"
}

\section{Astrid Nunn}

\section{(2) OpenEdition}

\section{Journals}

Édition électronique

URL : http://journals.openedition.org/abstractairanica/49424

DOI : 10.4000/abstractairanica.49424

ISBN : 1961-960X

ISSN : 1961-960X

Éditeur :

CNRS (UMR 7528 Mondes iraniens et indiens), Éditions de l'IFRI

Référence électronique

Astrid Nunn, « Maria G. Micale. "Clay Figurines in the Persian Achaemenid Near East as Seen from Tell Mardikh" », Abstracta Iranica [En ligne], Volume 40-41 | 2019, document 57, mis en ligne le 30 octobre 2019, consulté le 25 avril 2021. URL : http://journals.openedition.org/abstractairanica/49424 ; DOI : https://doi.org/10.4000/abstractairanica.49424

Ce document a été généré automatiquement le 25 avril 2021

Tous droits réservés 


\title{
Maria G. Micale. "Clay Figurines in the Persian Achaemenid Near East as Seen from Tell Mardikh"
}

\author{
Astrid Nunn
}

\section{RÉFÉRENCE}

Maria G. Micale. "Clay Figurines in the Persian Achaemenid Near East as Seen from Tell Mardikh" in P. Matthiae, F. Pinnock, M. D’Andrea (eds.). Ebla and Beyond. Ancient Near Eastern Studies after Fifty Years of Discoveries at Tell Mardikh. Proceedings of the International Congress Held in Rome, 15th-17th December 2014. Wiesbaden : Harrassowitz, 2018, p.

495-516

1 L'on sait depuis longtemps que de nombreuses terres-cuites achéménides ont été fouillées à Ebla et qu'elles ne sont pratiquement pas publiées. Deux articles récents s'y attachent (voir c.r. P. D'Amore : n58 dans ce numéro et cette même section d'Abstracta Iranica 40-41). L'A. pose le cadre d'une étude à venir. Outre le classement chronologique, la typologie et l'iconographie, son but sera de résoudre de nombreux problèmes précis. En fin de compte elle essayera de replacer ces images dans le contexte spécifique de la ville syrienne qu'est Ebla et de comprendre leur signification. L'un des résultats précis présenté dans cette contribution concerne la chronologie des plaquettes montrant des femmes dévêtues et vêtues. La séquence stratigraphique du contexte archéologique sur l'Acropole indiquerait que, contrairement à que l'on pensait jusqu'à présent, la femme vêtue et «à polos » serait plus ancienne que les types de femmes dévêtues. Cette chronologie montrerait que la femme vêtue d'aspect "grec » aurait rapidement été introduite par les Achéménides. Les terres cuites de femmes dévêtues auraient retrouvé leur place plus tard. 


\section{AUTEURS}

\section{ASTRID NUNN}

Université de Munich 